\title{
AEROSOL OPTICAL DEPTH (AOD) OVER FOUR INDONESIAN CITIES FROM THE AERONET MEASUREMENT: AN OVERVIEW
}

\author{
Aerosol Optical Depth (AOD) di Empat Kota Indonesia dari Pengukuran \\ Aeronet: Sebuah Gambaran Umum
}

\author{
Sheila Dewi Ayu Kusumaningtyas ${ }^{1)^{\star}}$ \\ 1) Agency for Meteorology, Climatology, and Geophysics of Indonesia (BMKG), Jl. Angkasa I, No.2, \\ Kemayoran, Jakarta 10720 \\ *E-mail: sheila.dewi@bmkg.go.id
}

\begin{abstract}
A large amount of aerosol, commonly known as Particulate Matter (PM), is emitted to the atmosphere from land-use conversion, urbanization, and the use of fossil fuels from a variety of sectors. Aerosol affect climate, environment, to human health. Each location might have different aerosols types due to various sources, sinks, and local characteristics. Aerosol Robotic Network (AERONET) has been established to investigate and monitor aerosol world-wide included in Indonesia. This work aims to study aerosol optical properties retrieved from AERONET in four locations namely Bandung, Jambi, Pontianak, and Palangkaraya. Seasonal and daily variability in $A O D$ and Angstrom exponent ( $\alpha$ ), also aerosol classification, is analyzed. The result shows that aerosol characteristics such as AOD and $\alpha$ in Bandung are different from Jambi, Palangkaraya, and Pontianak due to different aerosol sources. AOD clearly increases during the burning period (dry period) in Jambi, Palangkaraya, and Pontianak. The highest AOD monthly maximum recorded in Palangkaraya as of 4.51 during September. On the other hand, $A O D$ in Bandung does not show significant variation during dry and rainy season. Mixed aerosols (coarse and fine mode) are present in all locations. However, the dominance of fine mode is depicted from high percent frequency of occurrence in Jambi, Palangkaraya, Pontianak, and Bandung, which are 33.4\%, 31.38\%, 25.14\% (a range bin 1.6-1.8) and $37.16 \%$ ( $\alpha$ range bin 1.4-1.6) respectively. There was a period of $\alpha>1$ with $1<A O D<6$ in Jambi, Palangkaraya, and Pontianak suggesting smoke fire from peatland, while AOD close to 1 with $\alpha>1$ as the character of urban aerosol is prominent in Bandung.
\end{abstract}

Keywords: Aerosol Optical Depth, Indonesia, AERONET.

\section{Intisari}

Sejumlah besar aerosol, atau yang dikenal dengan partikulat, diemisikan ke atmosfer dari aktivitas konversi penggunaan lahan, urbanisasi, dan pembakaran bahan bakar fosil dari berbagai sektor. Aerosol memengaruhi iklim, lingkungan, hingga kesehatan manusia. Setiap lokasi memiliki jenis aerosol berbeda karena perbedaan sumber polusi dan cara penyerapannya, serta karakteristik lokal daerah tersebut. Aerosol Robotic Network (AERONET) dibentuk untuk menginvestigasi dan memantau aerosol di seluruh dunia termasuk di Indonesia. Tujuan dari penelitian ini untuk mempelajari sifat optik aerosol yang diperoleh dari AERONET di empat lokasi yaitu Bandung, Jambi, Pontianak, dan Palangkaraya. Variabilitas musiman dan harian parameter AOD dan Angstrom eksponen (a) serta klasifikasi aerosol juga dianalisis. Hasil dari studi menunjukkan karakteristik aerosol seperti $A O D$ dan a di Bandung berbeda dari Jambi, Palangkaraya, dan Pontianak karena perbedaan sumber aerosol. AOD meningkat selama periode kebakaran lahan (musim kemarau) di Jambi, Palangkaraya, dan Pontianak. Maksimum bulanan AOD tertinggi tercatat di Palangkaraya sebesar 4.51 pada September. Di sisi lain, AOD di Bandung tidak menunjukkan variasi yang besar pada musim kemarau dan hujan. Aerosol campuran (partikel kasar dan halus) terdapat di semua lokasi. Namun, dominasi aerosol berukuran halus digambarkan oleh tingginya frekuensi kejadian di Jambi, Palangkaraya, Pontianak, dan Bandung masing-masing 33,4\%, 31,38\%, 25,14\% (a range bin 1,6-1,8) dan 37,16\% (a range bin 1,4-1.6). Terdapat periode dimana $\alpha>1$ dengan $1<A O D<6$ di Jambi, Palangkaraya, dan Pontianak menunjukkan sumber aerosol berasal dari kebakaran asap dari lahan gambut, sementara $A O D$ mendekati 1 dengan $\alpha>1$ sebagai karakter dari aerosol perkotaan menonjol di Bandung.

Kata Kunci: Aerosol Optical Depth, Indonesia, AERONET. 


\section{INTRODUCTION}

Human activities such as land use conversion, urbanization, and combustion of fossil fuels have modified the chemical composition of the atmosphere. Those activities produce a lot of amount of aerosols and greenhouse gasses to the atmosphere. Aerosols, commonly known as particulate matter (PM), are one of the major species of air pollution. Aerosols in the troposphere can affect Earth's climate both direct and indirect.

Aerosols scatter and absorb the incoming solar radiation directly. They could also alter cloud amounts and properties by increase cloud condensation nuclei and cloud albedo as the indirect effect to climate (Lazaridis, 2011).

Aerosols are exist in the atmosphere in extremely variable concentration in space and time with a wide range of sizes, composition, optical and chemical properties. This is due to the very large heterogenity in aerosol sources and their relatively short residence time in the atmosphere (from hours to weeks) (Boucher, 2015).

The essential aerosols property that influence their chemical composition, optical properties, and determine how they are removed from the atmosphere as well as their impact to climate and human health, is particle size. Small or fine mode aerosols (defined as particulate matter with diameter $2.5 \mu \mathrm{m}$ or less) in the atmosphere derive mainly from gas-to-particle conversion (both from anthropogenic and biogenic emissions), while coarse-mode aerosols come mostly from natural sources such as sea-salt, desert dust, and sulfate produced over the ocean surface or volcanoes (Prospero et al., 2002), with some contributions from human activities. Fine particle has hazardous effect to human health as it reside for a long time in the atmosphere and can penetrate deep into the lungs (Khan et al., 2016). Aerosols also decrease visibility, thus affecting environment, livelihood, and economy (Kusumaningtyas \& Aldrian, 2016; Latha \& Badarinath, 2003; Seinfeld \& Pandis 2006; Han et al., 2012).

Tropospheric aerosols contain sulfate, ammonium, nitrate, sodium, chloride, and carbonaceous material are anthropogenic originated such as combustion process (Seinfeld \& Pandis, 2006). The relationship between anthropogenic emission and the increased of atmospheric aerosol over the past century has been studied. For example Heintzenberg (1989) and Solomon et al. (1989) studied the aerosol mass concentrations and composition in different regions of the troposphere. They measured the mass concentration and composition of tropospheric aerosol in remote, nonurban continental, and urban areas in United States of America.
Due to substantial effects of aerosols to environment and human health, aerosol monitorings and investigations have been established both by satellite remote sensing and ground-based measurements. The latter way is the easiest, simplest, and most accurate measurement such as Aerosol Robotic Network (AERONET).

The AERONET project is a federation of ground-based remote sensing aerosol networks established in early 1990s by National Aeronautics and Space Administration (NASA) in collaboration with international, national, and local agencies, private foundations, and individuals (Holben et al., 1998). During the establishment, 60 instruments were deployed world-wide such as North America, South America, Europe, Africa, and the Middle East. The AERONET since then has established more than 550 operational sites worldwide to measure the Aerosol Optical Depth (AOD) which is used in local investigations to characterize aerosols, assess atmospheric pollution and validate satellite retrieval (Dubovik et al., 2000). AERONET offers standardization for a ground-based regional to global scale aerosol monitoring and characterization network as well as data archive (Holben et al., 1998). This network is using Sun photometer instruments that measure direct solar and diffuse sky radiation at several wavelengths.

Aerosols distribution are also strongly influenced by the local meteorology and land cover type at a given location (Boucher, 2015). Aerosols environment in Indonesia might be different from other regions such as in Europe, America, and Africa. Aerosols in Europe and America are dominated from industrial and energy sectors, while desert dust and biomass burning are major sources in Africa. Asian aerosols are originated from urban pollution and biomass burning. However, each location in Indonesia might has different aerosol types due to different sources, sinks, and local characteristic. Numerous aerosols studies and investigations have been conducted using AERONET data in all over the world, however to my knowledge there is no paper yet on long term aerosols anaylsis using AERONET data in several locations in Indonesia.

The aim of this work is to study the climatology of aerosol optical properties retrieved from AERONET measurements in four different locations in Indonesia. Long term AERONET measurement has been carried out in Bandung, Palangkaraya, Pontianak, and Jambi. I here present the monthly AOD mesured at $500 \mathrm{~nm}$, the Angstrom exponent or $\alpha$ at $440-870 \mathrm{~nm}$ in those four cities. The characterization of the aerosol properties in different locations in Indonesia will give understanding and information on aerosols environment related to local sources and possible prevention or management efforts to manage aerosol pollution. 


\section{METHODS}

\subsection{Study Locations}

There are ten sites in Indonesia carry out the AERONET measurement. However due to complete long term data, this study only focuses in four different locations represent different sources and local meteorology (Figure 1).

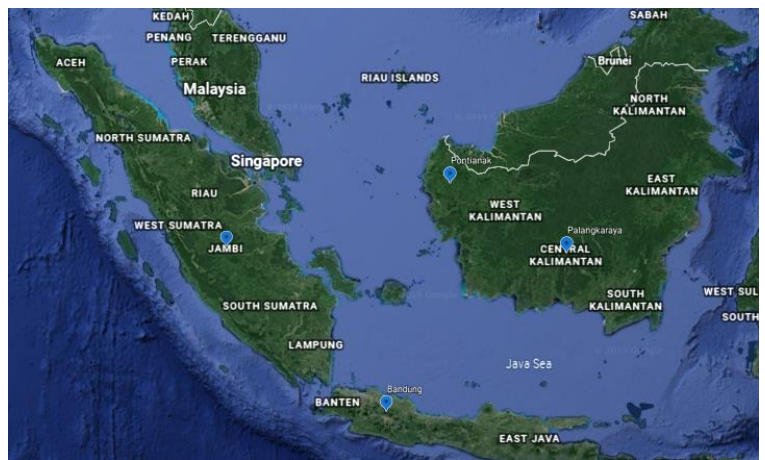

Figure 1. AERONET measurement sites.

The first site include in this paper is Bandung. The Sun photometer was installed on the roof top of one of the Bandung Institute of Technology (ITB) buildings since 2009. Bandung is densely-populated compared than Palangkaraya, Pontianak, and Jambi with total population 2.3 million (at the 2010 Census) and is categorized as big city. Bandung is an montaneous area with elevation $768 \mathrm{~m}$ (above sea level) and located in west Java. As a big city with growing economic development, Gross Domestic Product (GDP) 2017 of Bandung is 240.109.626 million IDR (BPS, 2019). This is much higher compared than Palangkaraya, Pontianak, and Jambi which are 9.476; 33.471; 189.868.125 IDR in same year respectively (BPS, 2019). As widely known that rapid economic development will contribute to air quality degradation by emitting larger amount of particulates with different characteristic or properties compared than other region with lower economic development.

Palangkaraya and Pontianak are located in central and west Kalimantan, have population of 220,962 and 554,764 inhabitants (at the 2010 Census) consecutively. Agriculture, forestry, and fisheries are the top three substantial contributors for Kalimantan economic growth. Palm oil and rubber are the main commodities. Both central and west Kalimantan owned more than 3 million ha peatland and stored about $\sim 11$ million ton of carbon (Ritung et al., 2011). Almost every year, Kalimantan experiences peatland fire which produces thick haze containing high aerosol loading.

Sun photometer from the AERONET was installed on the roof of the Tjilik Riwut Meteorology Station at latitude $2.23^{\circ}$ and longitude $113.94^{\circ}$. In Pontianak, the instrument was installed in the instrument site of Mempawah Climatological
Station. Sun photometer in Palangkaraya and Pontianak were installed since 2012.

Another AERONET site analyzed in this paper is Jambi. Jambi is located in Sumatera island and considered as a fire prone area. AERONET site in Jambi is located in Sultan Thaha Meteorological Station at latitude $1.63^{\circ}$ and longitude $103.65^{\circ}$. The AERONET Sun photometer was installed in Jambi since 2012.

\subsection{Instrumentation, Data Collection and Analysis}

Sun photometer instrument used in AERONET program is presented in Figure 2.

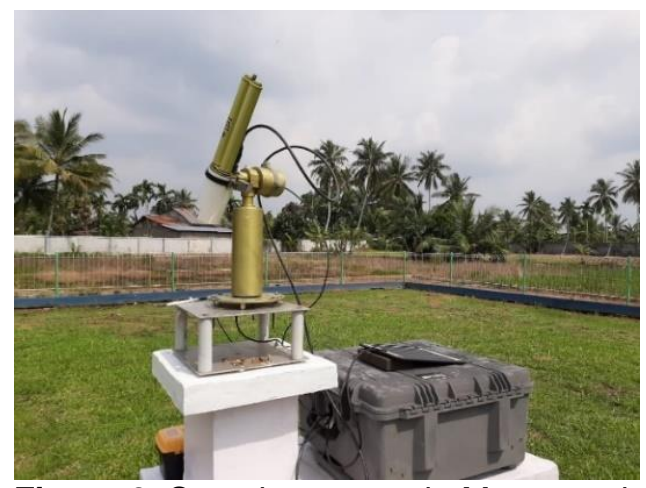

Figure 2. Sun photometer in Mempawah Climatological Station, Pontianak.

The Sun photometer is installed in each site in Bandung, Palangkaraya, Pontianak, and Jambi. This instrument measures the direct-beam radiances with a $1.2^{\circ}$ full field of view at least every $15 \mathrm{~min}$ at $340,380,440,500,675,870,940$, and $1020 \mathrm{~nm}$. The direct sun measurements take 8 seconds to scan all 8 wavelengths, with a sequence of 3 measurements (termed a triplet) taken 30 seconds apart at each wavelength within a one minute period. These solar extinction measurements are then used to compute AOD which is the main product (Holben et al., 1998; Giles, 2012).

\subsubsection{Aerosol Optical Depth (AOD)}

The AOD is the integral of the atmospheric extinction coefficient (scattering and absorbing aerosol) from the surface to the top of the atmosphere and an important parameter for visibility degradation (due to atmospheric pollution), solar radiation extinction, climate effects, and tropospheric corrections in remote sensing (Kaskaoutis et al., 2007). The AOD depends on the wavelength of the radiation. However, this paper only presents AOD in $500 \mathrm{~nm}$ because this wavelength lies in the middle of the visible range and also the peak of the solar spectrum where the maximal radiactive effect occurred (Carabali et al., 2017). Another parameter that is retrieved from AOD is Angstrom exponent $(\alpha)$. 


\subsubsection{Angstrom Exponent ( $\alpha$ )}

The aerosol size distribution strongly influences the spectral dependence of aerosol optical depth. The characterization of the spectral dependence of aerosol optical depth in the atmosphere is useful for identification of aerosol sources and aerosol evolution in time (Eck et al., 1999). The spectral dependence of AOD (or extinction coefficient) could be measured using a as the following equation (Angstrom, 1929):

$$
\alpha=-\frac{\ln \left(\tau_{a 1 /} \tau_{a 2}\right)}{\ln (\lambda 1 / \lambda 2)}
$$

where $\tau_{a 1}$ and $\tau_{a 2}$ are the AOD at wavelength of $\lambda_{1}$ and $\lambda_{2}$, respectively. The size distribution of aerosols is estimated from spectral aerosol optical depth with typicall wavelength from $440 \mathrm{~nm}$ to $870 \mathrm{~nm}$ (Eck et al., 1999). Therefore, the $\alpha$ is a good indicator of particle size. In addition, $\alpha$ contains information on the size of the scatterer. Angstrom exponent is 4 for scattering molecules. Particles of the accumulation mode (diameter $<1$ $\mu \mathrm{m}$ ) have $\alpha$ of about 2, and values close to 0 or slightly negative for coarse mode aerosol (Boucher, 2015).

The AERONET data are given in three categories: cloud-contaminated (level 1.0), cloudscreened (level 1.5), and cloud-screened and quality assured (level 2.0) (Eck et al., 2019). All AERONET data presented here are using level 2.0. This paper does not include measurements taken in 2019 due to the unavailability of level 2.0 data. To investigate aerosol characterization during dry and rainy season, this paper employes rainfall data obtained from each site.

\section{RESULTS AND DISCUSSIONS}

\subsection{Monthly Rainfall Climatology in Four AERONET Sites}

Figure 3 presents the cumulative monthly rainfall from 1988 to 2018 to show the type of rainfall in four selected AERONET sites. Dry season in Bandung starts on June to September and begins to rain on late October with average temperature $23.5^{\circ}$ Celcius. Bandung are included in seasonal zone meaning that there is a clear difference between dry and rainy season.

Palangkaraya and Pontianak have the equatorial semi monsoonal type of climate (Aldrian \& Susanto, 2003) and are not included in Indonesia seasonal zone according to BMKG. Pontianak lies right in the middle of the equator thus become one of the tropics with high temperatures and humidity throughout year. There is no clear difference between rainy and dry season in Palangkaraya and Pontianak. However, dry season in Palangkaraya and Pontianak usually occur between July to September sometimes to October where average rainfall reaches below $150 \mathrm{~mm} /$ month. According to
Indonesian Meteorological Office (BMKG), dry season onset is determined if the total amount of rainfall during the first 10 days is less than $50 \mathrm{~mm}$ and followed by the next two 10-days. According to BMKG, climate in Jambi is included in seasonal zone. Dry season in Jambi starts from June to September or early October.

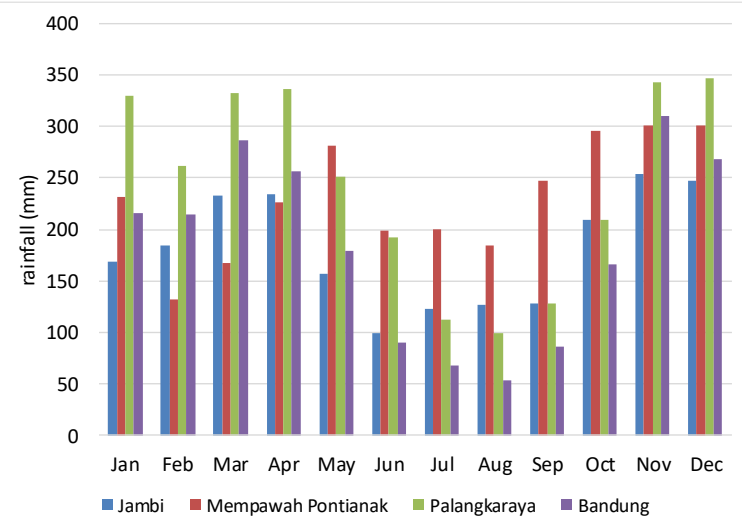

Figure 3. Cumulative monthly rainfall climatology at the four sites between 1988-2018.

\subsection{Monthly Variation of $A O D_{500}$ and $\alpha_{440-870}$ in Four AERONET Sites}

Figure 4 exhibits the monthly variation of the $A_{O D} D_{500}\left(A O D\right.$ at $500 \mathrm{~nm}$ ) and $\alpha_{440-870}$ (Angstrom exponent at $440-870 \mathrm{~nm}$ ) over the four sites. These graphs are presented in order to establish the different aerosol climatologies in four selected sites. As can be seen from Fig. 4a that the highest overall AOD monthly average was 1.63 (as well as presented in Table 1) and recorded in Jambi during October. As expected that the AOD increased during dry season on July and gradually downed on November in all sites. Interestingly, AOD had two high peaks in Jambi during February to March and August to October. Higher AOD monthly average on February to March was due to high AOD observed during same period in 2014. Details will be discussed in next section.

During measurement period, the lowest AOD was observed as 0.24 on April to May, while the highest was 1.63 on October. The monthly maximum value of $A O D$ was 4.10 also on October. During dry season on June to September, Jambi experienced recurrent forest and land fires. As a result, smoke particulate will be dominated and contributed to high aerosol loading in the atmosphere.

Kusumaningtyas et al. (2016) found a strong correlation between $A O D$ and hotspot number, while Vadrevu et al. (2014) found a significant enhancement in aerosols during the Riau fire episodes in 2013 shown by strong correlation of fire counts with Aerosol Absorption Optical Depth (AAOD). In addition, with the absence or reduced rainfall, the aerosols will remain in the atmosphere. Kusumaningtyas et al. (2016) found that AOD and rainfall correlate 
significantly. The standard deviation of AOD is higher during burning season from August to November $(0.45-0.77)$ as well as on February to March $(0.59-0.57)$ due to high variability in the intensity and phase of the fires (Kambezidis \& Kaskaoutis, 2008). On the other hand, AOD standard deviation is smaller for the whole season during measurement period.

In contrast with other sites, AOD in Bandung was quite stable for all months during the measurement period ranges from 0.25 to 0.5 , however slightly higher during dry season period from June to October. In general, AOD was much lower in Bandung compared than Jambi, Palangkaraya, and Pontianak. Overall monthly mean $\mathrm{AOD}_{500}$ in Bandung was 0.38. This is still lower than Chinese urban areas that was $>0.6$ (Che et al., 2015) and quite similar compared to Mexico city which was 0.34 (Carabali et al., 2017).

This finding implies that although Bandung considers as urban area and big city, it has better air quality (in term of aerosol polutant) compared than other cities in the world such as in China.
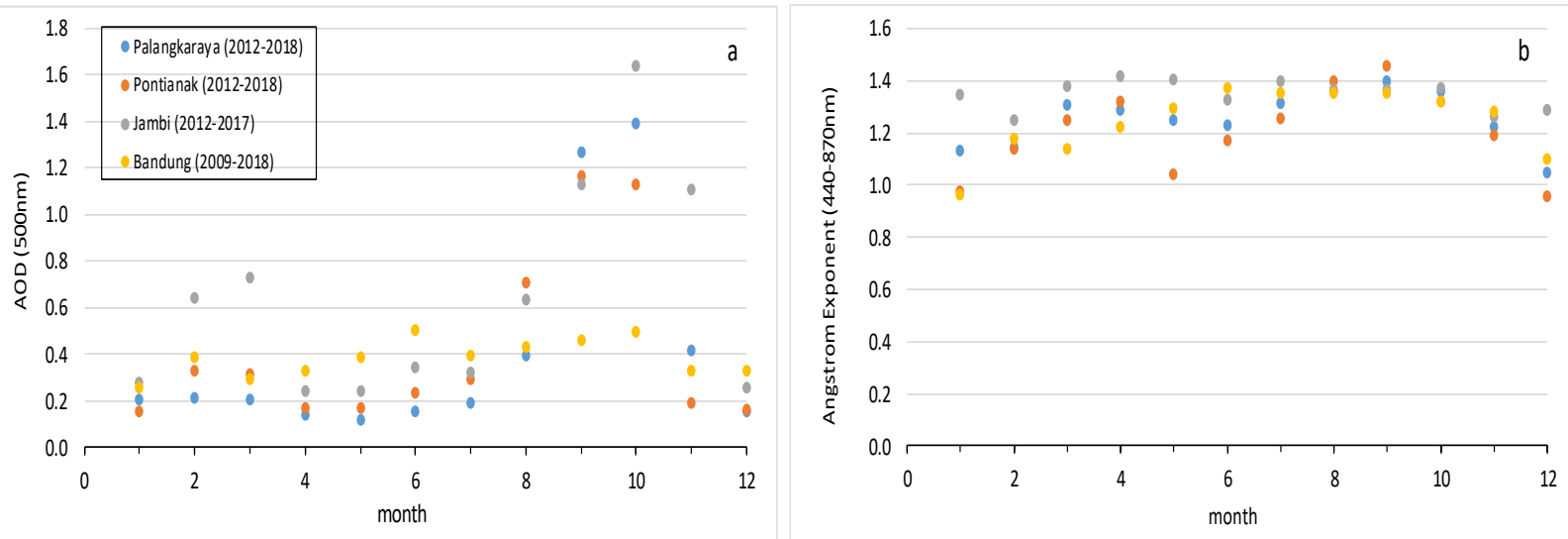

Figure 4. Monthly average of (a) AOD (500 nm) and (b) Angstrom Exponent (440-870 nm) in all selected sites for the whole period

Table 1. Monthly Mean and Maximum Values, as well as the Associated Standard Deviations (SD) of Aerosol Optical Depth at $500 \mathrm{~nm}$, Period and Number of Measurements in All Four Sites during Whole Period of Measurements.

\begin{tabular}{|c|c|c|c|c|c|c|c|c|c|c|c|c|}
\hline & \multicolumn{3}{|c|}{ Bandung } & \multicolumn{3}{|c|}{ Jambi } & \multicolumn{3}{|c|}{ Palangkaraya } & \multicolumn{3}{|c|}{ Pontianak } \\
\hline & $\begin{array}{c}\text { AOD } \\
\text { avg }\end{array}$ & $\begin{array}{l}\text { AOD } \\
\max \end{array}$ & $\begin{array}{c}S D \\
A O D\end{array}$ & $\begin{array}{c}\text { AOD } \\
\text { avg }\end{array}$ & $\begin{array}{l}\text { AOD } \\
\max \end{array}$ & $\begin{array}{c}\text { SD } \\
\text { AOD }\end{array}$ & $\begin{array}{c}\text { AOD } \\
\text { avg }\end{array}$ & $\begin{array}{c}\mathrm{AO} \\
\mathrm{D} \\
\max \end{array}$ & $\begin{array}{c}S D \\
A O D\end{array}$ & $\begin{array}{c}\text { AOD } \\
\text { avg }\end{array}$ & $\begin{array}{l}\text { AOD } \\
\max \end{array}$ & $\begin{array}{c}\text { SD } \\
\text { AO } \\
D\end{array}$ \\
\hline Jan & 0.25 & 0.48 & 0.16 & 0.28 & 0.31 & 0.04 & 0.21 & 0.37 & 0.11 & 0.16 & 0.20 & 0.03 \\
\hline Feb & 0.38 & 0.58 & 0.18 & 0.64 & 1.27 & 0.59 & 0.21 & 0.42 & 0.14 & 0.33 & 0.95 & 0.36 \\
\hline Mar & 0.29 & 0.37 & 0.08 & 0.73 & 1.59 & 0.57 & 0.20 & 0.31 & 0.07 & 0.31 & 0.62 & 0.18 \\
\hline Apr & 0.33 & 0.50 & 0.13 & 0.24 & 0.30 & 0.05 & 0.14 & 0.17 & 0.03 & 0.17 & 0.23 & 0.04 \\
\hline May & 0.39 & 0.55 & 0.08 & 0.24 & 0.35 & 0.10 & 0.12 & 0.14 & 0.02 & 0.17 & 0.33 & 0.11 \\
\hline Jun & 0.50 & 0.86 & 0.17 & 0.34 & 0.44 & 0.10 & 0.15 & 0.20 & 0.03 & 0.23 & 0.36 & 0.08 \\
\hline Jul & 0.39 & 0.66 & 0.14 & 0.32 & 0.46 & 0.14 & 0.19 & 0.22 & 0.05 & 0.29 & 0.39 & 0.10 \\
\hline Aug & 0.43 & 0.63 & 0.13 & 0.63 & 1.20 & 0.45 & 0.39 & 0.98 & 0.30 & 0.70 & 0.98 & 0.33 \\
\hline Sep & 0.46 & 0.66 & 0.11 & 1.13 & 1.65 & 0.68 & 1.27 & 4.51 & 1.56 & 1.16 & 3.50 & 1.34 \\
\hline Oct & 0.49 & 0.70 & 0.15 & 1.63 & 4.10 & 1.55 & 1.39 & 4.32 & 1.51 & 1.13 & 2.86 & 1.08 \\
\hline Nov & 0.33 & 0.37 & 0.04 & 1.11 & 1.62 & 0.77 & 0.42 & 1.55 & 0.52 & 0.19 & 0.48 & 0.15 \\
\hline Dec & 0.33 & 0.47 & 0.08 & 0.26 & 0.32 & 0.09 & 0.15 & 0.20 & 0.04 & 0.16 & 0.25 & 0.06 \\
\hline $\begin{array}{l}\text { Period } \\
\text { of } \\
\text { meas } \\
\text { ureme } \\
\text { nt }\end{array}$ & May 2 & $\begin{array}{l}9-\mathrm{De} \\
2018\end{array}$ & nber & & $\begin{array}{l}2012- \\
2017\end{array}$ & & & $\begin{array}{l}20 \\
\text { mbe }\end{array}$ & & & $\begin{array}{l}20 \\
\text { mbe }\end{array}$ & \\
\hline
\end{tabular}


The monthly variation of $\mathrm{AOD}_{500}$ during 2012 to 2018 in Palangkaraya shows similar pattern with Pontianak. AOD ranges from 0.12 to 1.39 and 0.16 to 1.16 in Palangkaraya and Pontianak respectively. High AOD also measured during burning season and started to increase from June and decrease on November along with the existence of natural rainfall. Overall highest monthly maximum of AOD was recorded in Palangkaraya during September and October as of 4.51 and 4.32 respectively indicating very high aerosol loading in the atmosphere.

Figure $4 b$ depicts the monthly mean $a_{440-870}$ in all selected sites. Ångstrom exponent $(\alpha)$ retrieved from the spectral AOD describes the aerosol-size distribution. All four sites exhibit large mean monthly values above 1 during measurement period except January and December in Palangkaraya and Bandung. Angstrom exponent $\alpha$ is $>1$ indicated that finemode (submicron with radii $\leq 0.5 \mu \mathrm{m}$ ) aerosols are dominant, while $\alpha<1$ is indicated the coarse-mode particle (radii $\geq 0.5 \mu \mathrm{m}$ ) (Barman et al., 2019; Carabali et al., 2017). Angstrom value in Jambi was almost stable throughout year. Palangkaraya and Pontianak experienced an increasing of a during dry season as a result of smoke from frequent biomass burning. The size distribution of smoke particles from biomass burning and urban emissions are considered as fine mode particles with typical radius between 0.005-0.5 $\mu \mathrm{m}$ (Dubovik et al., 2002). Kusumaningtyas et al. (2016) analyzed that $\alpha$ in Palangkaraya was varied mostly between 1 and 2 during 2012 to 2014 with the daily average of $\approx 1.26$ with a median of $\approx 1.34$ which indicates a fine mode particle regime.
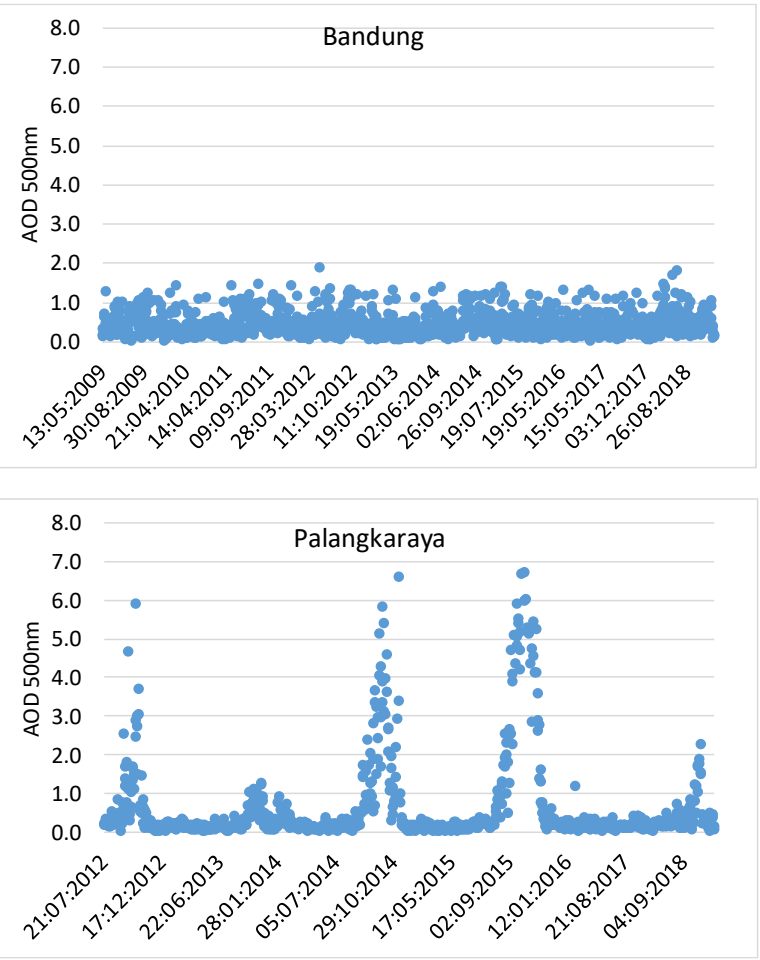

\subsection{Daily Variation of $A O D_{500}$ in Four AERONET Sites}

Daily average of $A^{O O D} 500$ in all selected sites are presented in Figure 5. Day to day variation of $A O D$ in Bandung does not show large variation. The percent frequency of occurrence shows a peak frequency of $37 \%$ for AOD with range 0.30.4 . Total AOD with values above 1 occurred in Bandung has the frequency of occurrence $11 \%$. Aerosol environment in Bandung is influenced by the local anthropogenic activities. According to Lestari \& Hendra (2019), the pollution levels in Bandung are incredibly exceeded the Indonesian Ambient Air Quality standard for particulate matter as an impact of urban activities. Particulate matter pollution in Bandung is originated mostly from transportation sector (Yudison et al., 2017; Hasan et al., 2019). During holiday season, Bandung is very crowded with worst traffic issue so that contribute to the increase of particulate matter and other pollutants to the atmosphere. Furthermore, its mountainous and hillside topography create the pollutants trap and rather difficult to disperse.

Daily variation of three sites (Jambi, Palangkaraya, and Pontianak) have similar pattern. AOD in Jambi, Palangkaraya, and Pontianak are highly varies showing that the level of aerosol loading in the atmosphere is also high which can be contributed from vehicles and transportation and other anthropogenic activities from urbanization development to biomass burning (Asmat et al., 2018). Very high AOD over 1 showing intense aerosol pollutant mainly from biomass burning (Holben et al., 1998) as the case from these three sites.
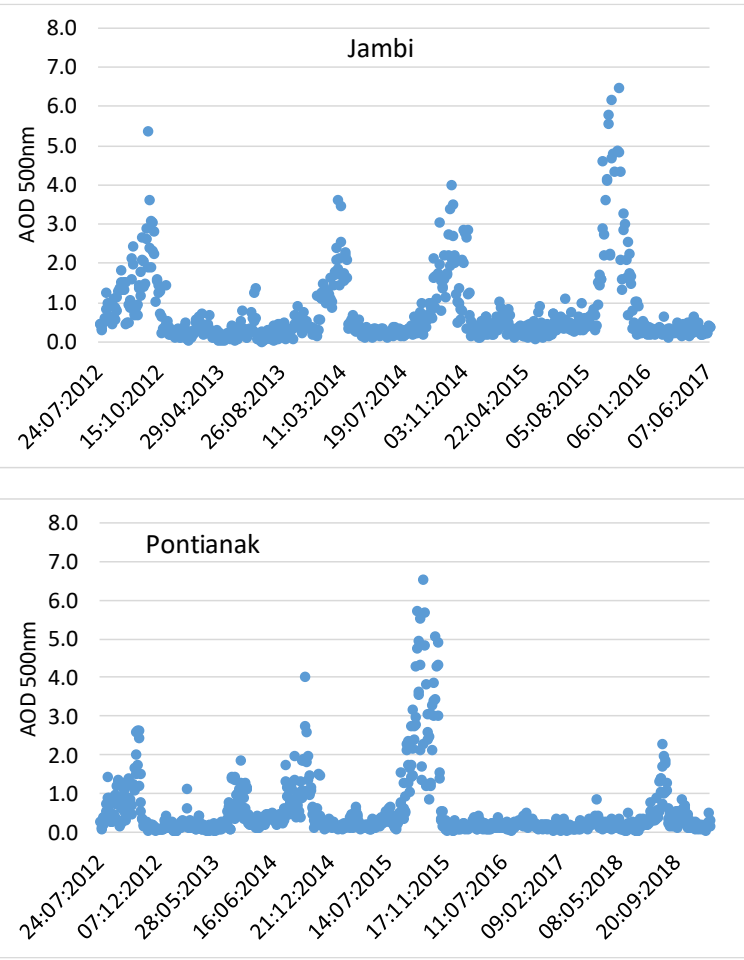

Figure 5. Mean daily values of $A O D_{500}$ for the whole period of measurements. 
In Sumatera, Jambi has the third largest peatland after Riau and South Sumatera province with total 621.089 ha (Wahyunto et al., 2014). As can be seen from the Figure 5 that AOD increased during August and peaked on October during whole period of measurement except in 2013. However, there was an increasing of AOD during February to March 2014 resulted an increase of monthly average. Large number of hotspot were found in Jambi during February to March 2014 which was 336. This number is higher compared than the previous year. High aerosol loading during this period might be also affected by the smoke from other parts outside Jambi. Unlike in Kalimantan, burning period in Sumatera sometimes occurs on February to March in addition to dry season.

According to Yulianti (2013), seasonal fire occurrence in Sumatera (mainly in North Sumatera, Jambi, and Riau) during February to March could be explained due to the two precipitation patterns and the dry season periods in those locations. Some part of Sumatera (Northern Sumatera, Jambi, and Riau) experience the winter fire peak in February. These fires correspond to the winter dry seasons which have the lowest daily mean precipitation (about 2 $\mathrm{mm} /$ day). Yulianti (2013) defined a dry season as the daily mean precipitation of $5 \mathrm{~mm} /$ day and found out that approximately two month of winter dry season in January and February. Therefore, people start to burn and explained the occurrence of high hotspot during that period.

Another explanation by Aldrian \& Utama (2010), the increase of hotspot number in February and March is due to strong cold surge episode. The cold surge arrives from dry and cold Siberia crossing the South China Sea (meridional wind) and brings dry and cold atmosphere that cools the sea surface temperature and bring dry air to Sumatera directly and increasing the hotspot number there.

AERONET measurement in Jambi also recorded extreme high AOD during 2015 dry season. As already known that 2015 was the El Nino year and Indonesia experienced very worst biomass burning and heavy thick smoke haze. The highest AOD was 6.46 on 26th October 2015. This very high $A O D$ as a result from peatland burning which are known to release considerable amount of smoke up to 8 to 9 times higher than from non- peatland source (Heil et al., 2007) However, unfortunately the Sun Photometer in Jambi site stopped from operating from 31 August to October 8, 2015 due to equipment malfunction. The highest frequency of occurrence was $52.4 \%$ with AOD range from $0.4-0.8$ and followed by $22.8 \%\left(A_{0 D} D_{500}=0.8-1.2\right)$.

Pattern of AOD daily variation in Palangkaraya and Pontianak are similar to each other with large variation due to smoke contribution. Kambezidis \& Kaskaoutis (2008) also mentioned that large AOD day to-day variations in certain place could be due to the combination of large variability in meteorological conditions (wind speed and direction, atmospheric stability, accumulation of aerosols in the boundary layer, aerosol dispersion) and the scavenging processes in the atmosphere, such as precipitation.

Palangkaraya experienced three highest peaks in 2012, 2014, and 2015. The highest AOD was 6.7 on September 29th 2015 . Eck et al. (2019) mentioned that the AOD in Palangkaraya was very high during 2015 and reached the maximum AOD that can be measured by AERONET (and all sunphotometers) which is $\sim 7$. In further, they noticed that these are the highest AOD ever estimated from AERONET data and unprecedented of smoke AOD values in any other site in the world having been previously reported in the scientific literature. Some of the African, South American, and Asia regions also experienced biomass burning with different type of vegetation. For example, AOD in Cuiaba-Brazil reached almost 2.4 due to burning taken place in tropical forest and grazing grasslands (Holben et al., 2001). Another example of high AOD (>1) due to vegetation (savannah) burning occurred in Mongu, Zambia (Holben et al., 2001). However, again the AOD values were much lower compared than in Indonesia due to different type of vegetation.

\subsection{Aerosol Classification: AOD versus a}

Figure 6 presents scatter plots mean daily of $A D_{500}$ and $\alpha_{440-870}$ for all sites. This graph is useful to deliver information on the aerosol type. As can be seen from the figure that all sites have large variation of $a$ ( $y$-axis) during the measurement period in particular Jambi. There is also a clear difference of aerosol characteristic in Bandung compared to the three other sites. The aerosol sources of Bandung mainly come from urban activities such as transportation and industrial sector.

The $\alpha$ in Bandung varies from 0.09-2.00 suggesting the present of aerosol mixture (fine and coarse-mode). The $\alpha$ is concentrated in 1.4 and 1.6 with percent frequency of occurrence are $37 \%$ and $33 \%$ indicated dominance of fine-mode aerosol. In urban areas, the AOD is variable and present high $\alpha$. Bandung appears to have a slightly higher of $A O D$ for urban aerosols close to 1 with $\alpha>1$ (yellow circle) compared than other urban areas in Southeast Asia such as Singapore $(A O D=0.4)$ and Kuching, Malaysia $(A O D=0.2)$ (Asmat et al., 2012 and Salinas et al., 2009). According to Asmat et al. (2012), urban aerosol is characteristic with $\alpha>1$ and $0.4<\mathrm{AOD}<1.0$ and consisted of fine particles (Asmat et al., 2012). 

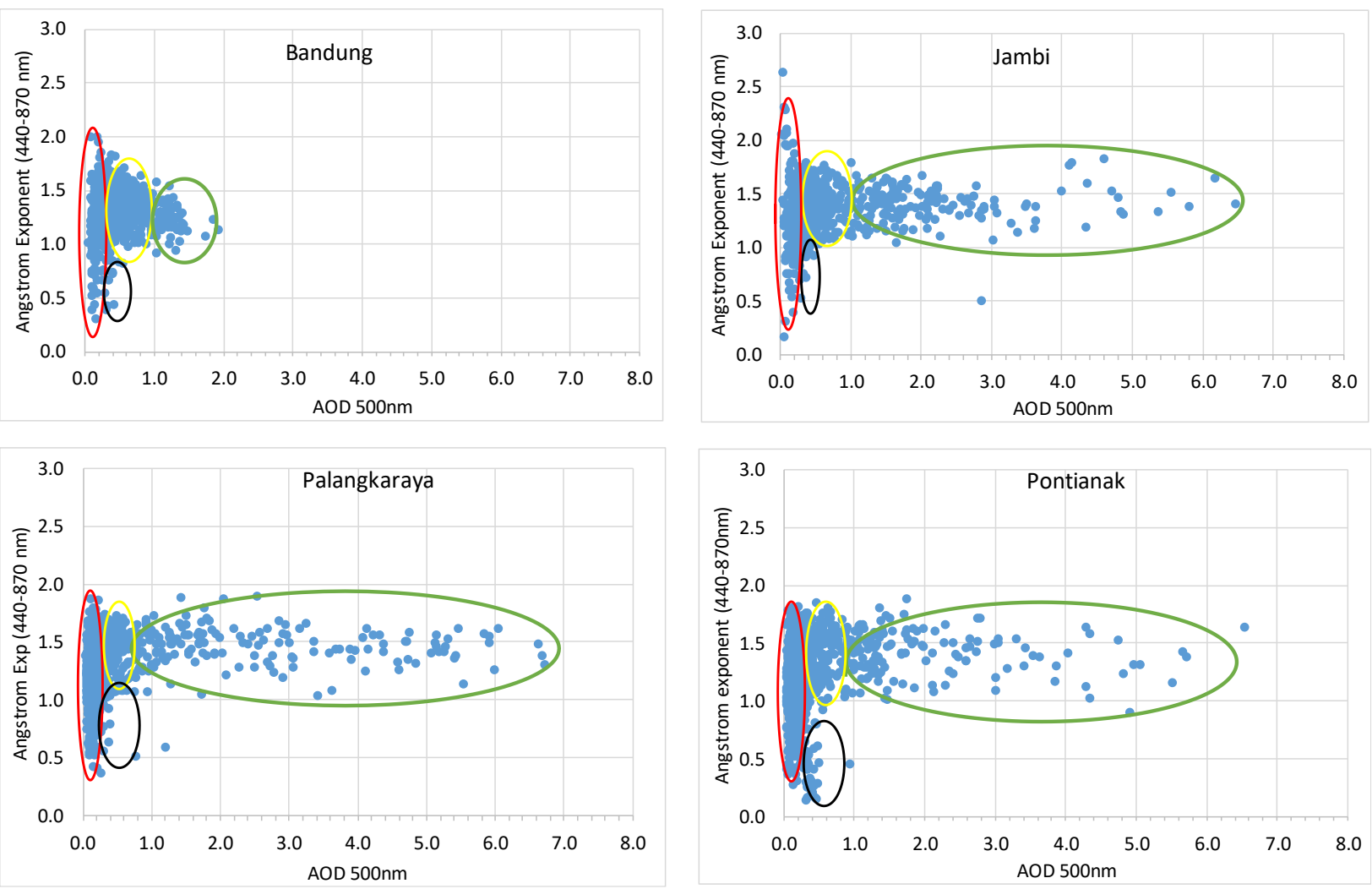

Figure 6. Scatter plot of daily average AOD at $500 \mathrm{~nm}$ and $\alpha$ at $440-870 \mathrm{~nm}$ in all four sites

This could be explained that the source of aerosols from transportation is intense in particular during weekend and holiday season which is almost 61 thousand of cars enter Bandung (BPS, 2018). Ambarsari et al. (2013) in their research found that the dominant sectors contributed to emission in Bandung are from transportation, domestic, and industry. In addition, fine particles in Bandung were contributed dominantly by vehicle's emission $(35 \%)$ and by secondary aerosol (26\%) (Lestari \& Mauliadi, 2009). Beside urban aerosol, there were period of $A O D>1$ and $\alpha>1$ indicated aerosol from biomass burning (green circle). Marine aerosol was found in the region of $A O D<0.3$ with $0.3<\alpha<2$ indicated with red circle. According to Toledano et al. (2007) and Salinas et al. (2013), the presence of marine aerosol could be identified with $0.3<\alpha<1.7$ and $0.1<\mathrm{AOD}<0.3$. Coarse mode aerosols were also found at $\alpha<0.5$ with $0.4<A O D<0.6$ suggesting the presence of industrial aerosols and fugitive dust (shown by the black circle) (Holben et al., 2001).

Large variation of AOD and $\alpha$ is distinct in Jambi compared than Bandung. The scatter plot of AOD and $\alpha$ in Jambi shows similar pattern with Palangkaraya and Pontianak with more variation on $\alpha$. The $\alpha$ varies from 0.17 to 2.63 . It is clear from the plot that there are high values of $\alpha$ at very high $A O D$ which is characteristic of small particle smoke aerosols indicated by green circle. This type of aerosols typically has accumulation modal radius values of $0.13-0.15 \mu \mathrm{m}$ (or fine-mode particles) (Holben et al., 2001). The highest percent frequency of occurrence is $33.4 \%$ at 1.6 -
1.7 a range bin thus suggesting dominance of smoke particles. This founding is in agreement with aerosol characteristic in Mongu, Zambia during burning period (Holben et al., 2001). There is also a period with $\alpha>1$ and $0.2<\mathrm{AOD}<1.0$ as an indication of continental and urban aerosols (yellow circle). Less than $3 \%$ of the observations exceed 2.0 with low $A O D<0.2$. According to (Holben et al., 1998), the wide range of $\alpha$ associated with the low optical depth cases may be due to a wide variety of aerosol types with different associated size distributions. Coarse mode of aerosols was also found and characterized by lower $\alpha<1$ with $0.4<A O D<0.5$ could be associated with the dust. Marine aerosol is characterized in the region $A O D<0.3$ and $0.2<\alpha<2$.

Aerosol characteristic in Palangkaraya and Pontianak are quite similar to each other. Both locations have also similar environment and climate. The $\alpha$ variation in Pontianak is a bit larger from 0.14-1.88 and 0.35-1.89 in Palangkaraya respectively. As well as in Jambi, one of the clearly feature is the dominance of fine mode aerosol which is shown by the high a with high AOD (green circle). The highest percent frequency of occurrence is $31.38 \%$ at $1.6-1.8 \alpha$ range bin. According to (Kusumaningtyas et al., 2016), aerosol in Palangkaraya is composed by mixed aerosol (dust, marine, urban and biomass burning).

Angstrom exponent in Pontianak varies from 0.14 to 1.88 . Similar with the Jambi and Palangkaraya, aerosol type in Pontianak were 
dominated by the particles between the $0<A O D<1$ with $\alpha>1$ or a clear fine mode regime. Another common feature in Pontianak (as well as in Jambi and Palangkaraya) is the large portion of $\alpha>1$ with $1<A O D<6.5$ showing very high aerosol loading with fine particles as the characteristics of smoke aerosols (Holben et al., 2001) could be from peatland burning. Eck et al. (2019) analyzed the aerosol properties using AERONET data in Palangkaraya during 2015 fire episode and found that the very high AOD with the character of small particles (indicated with high $\alpha$ ) and high Single Scattering Albedo (SSA) was typically produced from peatland burning. Eck et al. (2009) also found an extremely high AOD (400 nm) at almost 3.6 in fine mode distribution of aerosols during significant peat burning in Bonanza Creek, Alaska, which is similar with peat burning in Kalimantan and Sumatera.

Urban and continental aerosols were also indicated with $\alpha>1$ and $0.4<A O D<0.85$. Pontianak has larger portion of coarse mode aerosols compared than the three other sites. The percent frequent of occurrence for $\alpha \leq 1$ is $18.6 \%$, while Palangkaraya and Jambi are $9.85 \%$ and $4.66 \%$ respectively. This could be due to the presence of more marine aerosol in the form of sea-salt, considering located at the side of the coastal. More dust was also found in Pontianak compared than the three other sites with AOD around 0.3-0.5 with $\alpha<0.8$ black circle).

\section{CONCLUSION}

Analysis of $A O D$ and Angstrom exponent using the AERONET data was performed for four sites (Bandung, Jambi, Palangkaraya, and Pontianak) representative of different aerosol types and sources. The $A_{0 D} D_{500}$ and $\alpha_{440-870}$ over these sites can be summarized as follows:

(1) Aerosol characteristics such as AOD and Angstrom exponent in Bandung are different from Jambi, Palangkaraya, and Pontianak. This is due to different of aerosol sources and local characteristic (economic development, land type etc.). Jambi, Palangkaraya, and Pontianak experienced recurrent forest and land fire (mainly from peatland) in dry season during AERONET measurement period thus resulting very high $A O D$ and small particle. Meanwhile, AOD in Bandung was much lower than the other three sites contributed from urban activities.

(2) Large monthly variation of AOD is found in Jambi, Palangkaraya, and Pontianak ranges from 0.24-1.63; 0.12-1.39; and 0.16-1.16 respectively. AOD clearly increases during burning period (dry period) in Jambi, Palangkaraya, and Pontianak. Highest AOD monthly maximum was recorded in Palangkaraya as of 4.51 during September. The AOD decreased on November along with the existence of natural rainfall. During burning period and extreme drought in 2015, daily average of $A O D_{500}$ reached almost 7 in those three sites. On the other hand, AOD in Bandung does not show large variation during dry and rainy season ranges from $0.25-0.50$.

(3) Mixed aerosols (coarse and fine mode) are present in all locations. However, the dominance of fine mode is depicted from high percent frequency of occurrence in Jambi, Palangkaraya, Pontianak, and Bandung which are $33.4 \%, 31.38 \%, 25.14 \%$ ( $\alpha$ range bin 1.61.8 ) and $37.16 \%$ ( $\alpha$ range bin 1.4-1.6) respectively. There were a period of $\alpha>1$ with $1<\mathrm{AOD}<6$ in Jambi, Palangkaraya, and Pontianak suggesting smoke fire mainly from peatland (fine mode particles and very high aerosol loading), while AOD close to 1 with $\alpha>1$ as the character of urban aerosol appeared to be prominent in Bandung.

\section{REFERENCES}

Aldrian, E., Susanto, R.D. (2003). Identification of Three Dominant Rainfall Regions Within Indonesia and Their Relationship to Sea Surface Temperature. International Journal of Climatology, 23(12), 1435-1452. doi: 10.1002/joc.950.

Aldrian, E., Utama, G.S.A. (2010). Identifikasi dan Karakteristik Seruak Dingin (Cold Surge) Tahun 1995-2003. Jurnal Sains Dirgantara, 4(2), 107-127.

Ambarsari, N., Lestari, P., Sofyan, A. (2013). Inventarisasi Emisi Black Carbon, Prekursor Ozon (CO, NOx, Spesi VOC) dan Penentuan Ozone Formation Potential (Studi Kasus: Bandung Raya). Program Studi Teknik Lingkungan. Fakultas Teknik Sipil dan Lingkungan. Bandung.

Angstrom, A. (1929). On the AtmosphericTransmission of Sun Radiation and on Dust in the Air. Geografisika Annaler, 11(2), 156-166. doi: 10.1080/20014422.1929.11880498

Asmat, A., Jalal, K.A., Ahmad, N. (2012). Variability of Optical Properties for Atmospheric Aerosol in Kuching City Using AERONET Sunphotometer. Open Systems (ICOS), 2012 IEEE Conference on Open System, 21-24 Oct. 2012, 1-6.

Asmat, A., Jalal, K.A., Deros, S.N.M. (2018). Aerosol Properties over Kuching, Sarawak from Satellite and Ground-Based Measurements. Land-Atmospheric Research Applications in South and Southeast Asia, Springer Remote Sensing/Photogrammetry, K.P. Vadrevu et al. (eds.), 447-469. doi: 10.1007/978-3-31967474-2 21

Barman, N., Saha, B., Roy, R., Kundu, S.S., Borgohain, A., Raju, P.L.N. (2019). Investigation of Curvature Effect of Ångström Exponent to Classify the Aerosol 
Types over the Region of Interest $\left(88^{\circ}-98^{\circ}\right.$ $\mathrm{E}$ and $\left.20^{\circ}-30^{\circ} \mathrm{N}\right)$. Atmospheric Pollution Research, 10(2), 363-373. doi: 10.1016/j.apr.2018.09.002

BPS. (2019). Kota bandung dalam Angka 2018. https://bandungkota.bps.go.id/publication/2 018/08/16/a2782ae62042b1aee91fb4bc/ko ta-bandung-dalam-angka-2018.html

Boucher, O. (2015). Atmospheric Aerosols. Atmospheric Aerosols, Properties and Climate Impacts, 9-24. Springer, Dordrecht. doi: 10.1007/978-94-017-9649-1_2

Carabali, G., Estévez, H.R., Valdés-Barrón, M., Bonifaz-Alfonzo, R., Riveros-Rosas, D., Velasco-Herrera, V.M., Vázquez-Gálvez, F.A. (2017). Aerosol Climatology over the Mexico City Basin: Characterization of Optical Properties. Atmospheric Research, 194, 190-201. doi: 10.1016/j.atmosres.2017.04.035

Che, H., Zhang, X.Y., Xia, X., Goloub, P., Holben, B., Zhao, H., Wang, Y., Zhang, X.C., Wang, H., Blarel, L. \& Damiri, B., Zhang, R., Deng, X., Ma, Y., Wang, T., Geng, F., Qi, B., Zhu, J., Yu, J., Chen, Q., Shi, G. (2015). GroundBased Aerosol Climatology of China: Aerosol Optical Depths from the China Aerosol Remote Sensing Network (CARSNET) 2002-2013. Atmospheric Chemistry and Physics, 15(13), 7619-7652. doi: 10.5194/acp-15-7619-2015

Dubovik, O., King, M.D. (2000). A Flexible Inversion Algorithm for the Retrieval of Aerosol Optical Properties from Sun and Sky Radiance Measure. Journal of Geophysical Research, 105, 20673-20696. doi: 10.1029/2000JD900282

Eck, T.F., Holben, B.N, Giles, D.M., Slutsker, I., Sinyuk, A., Schafer, J.S., Smirnov, A., Sorokin, M., Reid, J.S., Sayer, A.M., Hsu, N.C., Shi, Y.R., Levy, R.C., Lyapustin, A., Rahman, M.A., Liew, S.C., Cortijo, S.V.S., Li, T., Kalbermatter, D., Keong, K.L., Yuggotomo, M.E., Aditya, F., Mohamad, M., Mahmud, M., Chong, TK., Lim, H.S., Choon, Y.E., Deranadyan, G., Kusumaningtyas, S.D.A., Aldrian, E. (2019). AERONET Remotely Sensed Measurements and Retrievals of Biomass Burning Aerosol Optical Properties During the 2015 Indonesian Burning Season. Journal of Geophysical Research: Atmospheres, 124(8), 4722-4740. doi: 10.1029/2018JD030182.

Eck, T.F., Holben, B.N., Reid, J.S., Dubovik, O., Smirnov, A., O'neill, N.T., Slutsker, I. Kinne, S.(1999). Wavelength Dependence of the Optical Depth of Biomass Burning, Urban, and Desert Dust Aerosols. Journal of Geophysical Research: Atmospheres, 104(D24), 31333-31349. doi: 10.1029/1999JD900923

Eck, T. F., Holben, B.N., Reid, J.S., Sinyuk, A.,
Hyer, E.J., O'Neill, N.Y., Shaw, G.E., Vande Castle, J.R., Chapin, F.S., Dubovik, O., Smirnov, A., Vermote, E., Schafer, J.S., Giles, D., Slutsker, I., Sorokine, M., Newcomb, W.W. (2009). Optical Properties of Boreal Region Biomass Burning Aerosols in Central Alaska and Seasonal Variation of Aerosol Optical Depth at an Arctic Coastal Site. Journal of Geophysical Research: Atmosphere, 114, D11201. doi: 10.1029/2008JD010870.

Giles, D.M. (2012). A Study of Remotely Sensed Aerosol Properties from Ground-Based Sun and Sky Scanning Radiometers. Dissertation. Department of Atmospheric and Oceanic Science, University of Maryland.

Han, S., Bian, H., Zhang, Y.,Wu, J., Wang, Y., Tie, X., Li, Y., Li, X., Yao, Q. (2012). Effect of Aerosols on Visibility and Radiation in Spring 2009 in Tianjin, China. Aerosol and Air Quality Research, 12, 211-217. doi: 10.4209/aaqr.2011.05.0073

Hasan, N. Y., Driejana,. Sulaeman, A., Ariesyady, H.D. (2019). Chemical Composition and Sources Attribution of Rainwater in Bandung Area, Indonesia. International Journal of GEOMATE, 17(64), 131-138. doi: 10.21660/2019.64.87856

Heil, A. (2007). Indonesian Forest and Peat Fires: Emissions, Air Quality, and Human Health. Dissertation. Max Planck Institute for Meteorology.

Heintzenberg, J. (1989). Fine Particles in the Global Troposphere - a Review. Tellus B, $41 B(2)$, 149-160. doi: 10.1111/j.16000889.1989.tb00132.x

Holben, B.N., Eck, T.F., Slutsker, I., Tanre, D., Buis, J.P., Setzer, A., Vermote, E., Reagan, J.A., Kaufman, Y., Nakajima, T., Lavenu, F., Jankowiak, I., Smirnov. A. (1998). AERONET - A Federated Instrument Network and Data Archive for Aerosol Characterization. Remote Sensing Environment, 66(1), 1-16. doi: 10.1016/S0034-4257(98)00031-5

Holben, B.N., Tanré, D., Smirnov, A., Eck, T.F., Slutsker, I., Abuhassan, N., Newcomb, W.W., Schafer, J.S., Chatenet, B., Lavenu, F., Kaufman, Y.J., Castle, J., Setzer, A., Markham, B., Clark, D., Frouin, R., Halthore, R., Karneli, A., O'Neill, N.T., Pietras, C., Pinker, R.T., Voss, K., Zibordi, G. (2001). An Emerging Ground Based Aerosol Climatology: Aerosol Optical Depth from AERONET. Journal of Geophysical Research: Atmospheres, 106(D11), 12067-12097. doi: 10.1029/2001JD900014

Kambezidis, H. D., Kaskaoutis, D.G. (2008). Aerosol Climatology over Four AERONET Sites: An Overview. Atmospheric Environment, 42(8), 1892-1906. doi: 10.1016/j.atmosenv.2007.11.013 
Kaskaoutis, D.G., Kambezidis, H.D., Hatzianastassiou, N., Kosmopoulos, P.G., Badarinath, K.V.S. (2007). Aerosol Climatology: Dependence of the Angstrom Exponent on Wavelength over Four AERONET Sites. Atmospheric Chemistry and Physics Discussions, 7, 7347-7397. doi: 10.5194/acpd-7-7347-2007

Khan, M.F., Latif, M.T., Saw, W.H., Amil, N., Nadzir, M.S.M., Sahani, M., Tahir, N.M., Chung, J.X. (2016). Fine Particulate Matter in the Tropical Environment: Monsoonal Effects, Source Apportionment, and Health Risk Assessment. Atmospheric Chemistry and Physics, 16, 597-617. doi: 10.5194/acp-16-597-2016

Kusumaningtyas, S.D.A., Aldrian, E. (2016). Impact of the June 2013 Riau Province Sumatera Smoke Haze Event on Regional Air Pollution. Environment Research Letter, 11(7), 75007-75017, doi: 10.1088/17489326/11/7/075007.

Kusumaningtyas, S.D.A., Aldrian, E., Rahman, M. A., Sopaheluwakan, A. (2016). Aerosol Properties In Central Kalimantan Due to Peatland Fire. Aerosol and Air Quality Research, 16, 2757-2767. doi: 10.4209/aaqr.2015.07.0451

Latha, K.M., Badarinath, K.V.S. (2003). Black Carbon Aerosols over Tropical Urban Environmental - A Case Study. Atmospheric Research, 69, 125-133. doi: 10.1016/j.atmosres.2003.09.001

Lazaridis, M. (2011). First Principles of Meteorology and Air Pollution. Environmental Pollution, 19. Springer, Dordrecht. doi: 10.1007/978-94-007-01625_2

Lestari, P., Hendra, Y. (2019). Fine and Coarse Particle Concentration and Composition Measured in Urban and Non Urban Area Bandung, West Java-Indonesia. IOP Conference Series: Earth and Environmental Science Vol. 303, 012043. doi: 10.1088/1755-1315/303/1/012043

Lestari, P., Mauliadi, Y.D. (2009). Source Apportionment of Particulate Matter at Urban Mixed Site in Indonesia Using PMF. Atmospheric Environment, 43(10), 17601770. doi: 10.1016/j.atmosenv.2008.12.044

Prospero, J.M., Ginoux, P., Torres, O., Nicholson, S.E., Gill, T.E. (2002). Environmental Characterization of Global Sources of Atmospheric Soil Dust Derived from the NIMBUS 7 Total Ozone Mapping Spectrometer (TOMS) Absorbing Aerosol Product. Reviews of Geophysics, 40(1), 2.1-2.31. doi: 10.1029/2000RG000095
Ritung, S., Wahyunto., Nugroho, K., Sukarman., Hikmatullah., Suparto., Tafakresnanto, C. (2011). Peta Lahan Gambut Indonesia, skala 1:250.000. Balai Besar Penelitian dan Pengembangan Sumberdaya Lahan Pertanian, Kementerian Pertanian.

Salinas, S.V., Ning, C.B., Liew, S.C. (2009). Characterization of Aerosol Physical and Optical Properties from a Combination of Ground-Based and Hand-Held SunPhotometer Data of Singapore. Proceeding of International Geoscience and Remote Sensing (IGARSS), IEEE International Symposium.

Seinfeld, J.H., Pandis, S.N. (2006). Atmospheric Chemistry and Physics, from Air Pollution to Climate Change. Second Edition. John Wiley \& Sons, New Jersey.

Solomon, P.A., Fall, T., Salmon, L., Cass, G.R., Gray, H.A., Davidson, A. (1989). Chemical Characteristic of PM10 Aerosols Collected in the Los Angeles Area. Journal Air Pollution Control Association, 39(2), 154163. 10.1080/08940630.1989.10466515

Toledano, C., Cachorro, V.E., Berjon, A., de Frutos, A.M., Sorribas, M., de la Morena, B.A., Goloub, P. (2007). Aerosol Optical Depth and Angstrom Exponent Climatology at El Arenosillo AERONET Site (Huelva, Spain). Quarterly Journal of the Royal Meteorological Society, 133, 795-807. doi: 10.1002/qj.54

Vadrevu, K.P., Lasko, K., Giglio, L., Justice, C. (2014). Analysis of Southeast Asian Pollution Episode During June 2013 Using Satellite Remote Sensing Datasets. Environmental Pollution, 195, 245-256. doi: 10.1016/j.envpol.2014.06.017

Wahyunto., Nugroho, K., Rintung, S., Sulaeman, Y. (2014). Indonesian Peatland Map: Method, Certainty and Uses. Pengelolaan Berkelanjutan Lahan Gambut Terdegradasi, 81-96. Jakarta

Yudison, A., Driejana., Reksowardojo, I.K., Sulaeman, A. (2017). Motorcycle Emission Profiles in Bandung City, Indonesia. SAE Technical Paper (No. 2017-32-0076).

Yulianti, N. (2013). The Influence of Precipitation Patterns on Recent Peatland Fires in Indonesia. Dissertation. Graduate School of Engineering, Hokkaido University 